\title{
SISTEM PENDIDIKAN ANAK USIA DINI DALAM KONSEP ISLAM (Analisis dalam Teoritis dan Praktis)
}

\author{
Buyung Surahman \\ Dosen Fakultas Tarbiyah dan Tadris IAIN Bengkulu \\ buyungsurahman@iainbengkulu.ac.id
}

\begin{abstract}
This article aims to reveal how the education system developed for early childhood in the Islamic concept, which includes curriculum, methods and evaluation of education. The method used in this paper is descriptive qualitative method. The results of the discussion indicate that the education that should be given to early childhood, is to include; first, the aqidah education, this is given because Islam puts the education of faith in the most fundamental position, Second, the Education of worship, so that someday they grow into beings who really piety, that is the devout man to carry out all religious commands and obedient also in steer clear of any ban. Third, moral education, in order to educate morals to the children, in addition to be given the right example, should also be shown about how to respect and to manners with fellow human beings. Islamic educational methods that can and should be applied to early childhood educational activities are exemplary methods, methods of practice and practice, game methods, songs, and stories, methods of targhib and tarhib, methods of praise and flattery and inculcation of good habits. The evaluation for the assessment of the educational process of children at an early age can be done in various ways, among others through the observation and recording of anecdotes which is a record of the attitude and behavior of children.
\end{abstract}

Abstrak: Artikel ini bertujuan untuk mengungkap tentang bagaimana sistem pendidikan yang dikembangkan kepada anak usia dini dalam konsep Islam, yang meliputi kurikulum, metode dan evaluasi pendidikannya. Adapun metode yang digunakan dalam penulisan ini adalah metode deskriptif kualitatif. Hasil pembahasan menunjukkan bahwa pendidikan yang harus diberikan kepada anak usia dini, adalah meliputi; pertama, pendidikan akidah, hal ini diberikan karena Islam menempatkan pendidikan akidah pada posisi yang paling mendasar Kedua, Pendidikan ibadah, agar kelak mereka tumbuh menjadi insan yang benar-benar takwa, yakni insan yang taat melaksanakan segala perintah agama dan taat pula dalam menjauhi segala larangannya. Ketiga, Pendidikan akhlak, dalam rangka mendidik akhlak kepada anak-anak, selain harus diberikan keteladanan yang tepat, juga harus ditunjukkan tentang bagaimana menghormati dan bertata krama dengan sesama manusia.Metode pendidikan Islam yang dapat dan layak diterapkan pada kegiatan pendidikan terhadap anak usia dini, adalah metode keteladanan, metode latihan dan pengamalan, metode permainan, nyanyian, dan cerita, metode targhib dan tarhib,metode pujian dan sanjungan serta menanamkan kebiasaan yang baik. Adapun evaluasi bagi penilaian proses pendidikan anak di usia dini dapat dilakukan dengan berbagai cara, antara lain melalui pengamatan dan pencatatan anekdot yang merupakan catatan tentang sikap dan perilaku anak.

Kata Kunci: Sistem Pendidikan, Anak Usia Dini,Konsep Islam

\section{Pendahuluan}

Dalam pandangan Islam anak merupakan amanah di tangan kedua orang tuanya. Hatinya yang bersih merupakan permata yang berharga, lugu dan bebas dari segala macam ukiran dan gambaran. Ukiran berupa didikan yang baik akan tumbuh subur pada diri anak, sehingga ia akan berkembang dengan baik dan sesuai ajaran Islam, dan pada akhirnya akan meraih kebahagiaan di dunia dan di akhirat. Jika anak sejak dini dibisakan dan dididik dengan hal-hal yang baik dan diajarkan kebaikan kepadanya, ia akan tumbuh dan berkembang dengan baik dan akan memperoleh kebahagiaan serta terhindar dari kesengaraan/siksa baik dalam hidupnya di dunia maupun di akhirat kelak. Hal ini senada dengan firman Allah:

34 NUANSA Vol. XI, No. 1, Juni 2018 
Buyung Surahman I Sistem Pendidikan Anak Usia Dini Dalam Konsep Islam 35

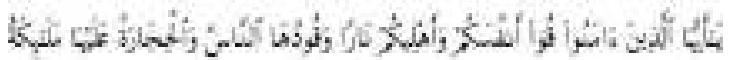

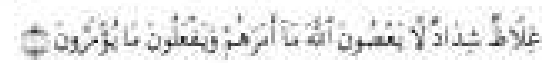

Artinya: "Hai orang-orang yang beriman, peliharalah dirimu dan keluargamu dari api neraka yang bahan bakarnya adalah manusia dan batu; penjaganya malaikat-malaikat yang kasar, yang keras, yang tidak mendurhakai Allah terhadap apa yang diperintahkan-Nya kepada mereka dan selalu mengerjakan apa yang diperintahkan."'

Terhadap ayat ini Ibnu Kasir dalamn tafsirnya menjelaskan, bahwa ayat ini menganjurkan kepada setiap individu muslim bertakwa kepada Allah dan perintahkanlah kepada keluargamu untuk bertakwa kepada Allah. Ibnu Kasir menjelaskan bahwa Qatada mengatakan bahwa engkau perintahkan mereka untuk taat kepada Allah dan engkau cegah mereka dari perbuatan durhaka terhadapNya, dan hendaklah engkau tegakkan terhadap mereka perintah Allah dan engkau anjurkan mereka untuk mengerjakannya serta engkau bantu mereka untuk mengamalkannya. Jika engkau melihat di kalangan keluargamu suatu perbuatan maksiat kepada Allah, maka engkau harus cegah mereka darinya dan engkau larang mereka melakukannya.

Jika dalam keluarga muslim telah mengajarkan anak-anaknya akan perlunya menghormati dan menghargai orang tua serta orang-orang dewasa lainnya, maka secara tidak sadar orang tua telah mengajarkan nilai-nilai moral yang sangat tinggi untuk menjalani kehidupan selanjutnya. ${ }^{2}$ Hal yang sama juga dikemukakan Ad-Dahlak dan Muqatil, bahwa sudah merupakan suatu kewajiban bagi seorang muslim mengajarkan kepada keluarganya, baik dari kalangan kerabatnya ataupun budakbudaknya, hal-hal yang difardukan oleh Allah dan mengajarkan kepada mereka hal-hal yang dilarang oleh Allah yang harus mereka jauhi. ${ }^{3}$

'QS. At Tahrim: 6

${ }^{2}$ R.A. Anggraeni Notosrijoedono, Menanamkan Kecerdasan Moral Sejak Anak Usia Dini Pada Keluarga Muslim, JURNAL TARBIYAH, Vol. 22, No. 1, Januari-Juni 2015, hlm. 135

${ }^{3} \mathrm{Al}$ Imam abul Fida Ismaillbnu Kasir Ad-Dimasyqi, Tafsir Al Qur'an al'Azim, terjemahan Bahrum Abu Bakar, Tafsir Ibnu Kasir..., hlm. 416
Berdasarkan ayat tersebut, dipahami bahwa orang tua memiliki kewajiban untuk memelihara diri dan keluarga (anak-anaknya) dari siksaan api neraka. Cara yang dapat dilakukan oleh orang tua ialah mendidiknya, membimbingnya dan mengajari akhlak-akhlak yang baik. Kemudian orang tua harus menjaganya dari pergaulan yang buruk, dan jangan membiasakannya berfoya-foya, jangan pula orang tua menanamkan rasa senang bersolek dan hidup dengan sarana-sarana kemewahan pada diri anak, sebab kelak anak akan menyia-nyiakan umurnya hanya untuk mencari kemewahan jika ia tumbuh menjadi dewasa, sehingga ia akan binasa untuk selamanya. Akan tetapi seharusnya orang tua sejak dini mulai mengawasi pertumbuhannya dengan cermat dan bijaksana sesuai dengan tuntutan pendidikan Islam.

Dari uraian di atas kiranya dapat disebutkan bahwa tujuan pendidikan anak usia dini dalam pandangan Islam adalah memelihara, membantu pertumbuhan dan perkembangan fitrah manusia yang dimiliki anak. Atau dengan kata lain bahwa pendidikan anak usia dini dalam pendidikan Islam bertujuan untuk menanamkan nilai-nilai keislaman kepada anak sejak dini, sehinga dalam perkembangan selanjutnya anak menjadi manusia muslim yang kaffah, yang beriman dan bertaqwa kepada Allah SWT. Hidupnya terhindar dari kemaksiatan, dan dihiasi dengan ketaatan dan kepatuhan serta oleh amal soleh yang tiada hentinya. Kondisi seperti inilah yang dikehendaki oleh pendidikan Islam, sehingga kelak akan mengantarkan peserta didik pada kehidupan yang bahagia di dunia maupun di akhirat.

Dengan demikian, penulis merasa perlu membahas tentang bagaimana sistem pendidikan yang dikembangkan kepada anak usia dini dalam konsep Islam, baik secara teoritis maupun praktiknya, yang meliputi kurikulum, metode dan evaluasi pendidikannya. Adapun metode yang digunakan dalam penulisan ini adalah metode deskriptif kualitatif.

\section{Pembahasan}

\section{Kurikulum Pendidikan Anak Usia Dini Dalam Konsep Islam}

Ada berbagai bentuk kurikulum yang dikembangkan oleh para ahli dalam pendidikan anak usia dini. Ada yang disebut dengan Kurikulum terpisahpisah, yakni kurikulum mempunyai mata pelaja- 
36 NUANSA Vol. XI, No. 1, Juni 2018

ran yang tersendiri satu dengan lainnya tidak ada kaitannya, karena masing-masing mata pelajaran mempunyai organisasi yang terintegrasikan. Ada pula Kurikulum saling berkaitan, yakni antara masing-masing mata pelajaran ada keterkaitan, antara dua mata pelajaran masih ada kaitannya. Dengan demikian anak mendapat kesempatan untuk melihat keterkaitan antara mata pelajaran, sehingga anak masih dapat belajar mengintegrasikan walaupun hanya antara dua mata pelajaran. Kemudian ada pula yang dinamai dengan Kurikuluim Terintegrasikan, dalam kurikulum ini anak mendapat pengalaman luas, karena antara satu mata pelajaran dengan mata pelajaran lain saling berkaitan. ${ }^{4}$

Dalam kaitannya dengan materi pendidikan untuk anak usia dini, Ibnu Sina telah menyebutkan dalam bukunya yang berjudul As-Siyasah, ide-ide yang cemerlang dalam mendidik anak. Dia menasihati agar dalam mendidik anak dimulai dengan mengajarkannya al Qur'an al-Karim yang merupakan persiapan fisik dan mental untuk belajar. Pada waktu itu juga anak-anak belajar mengenal huruf-huruf hijaiyah, cara membaca, menulis dan dasar-dasar agama. Setelah itu mereka belajar meriwayatkan sya'ir yang dimulai dari rojaz kemudian qashidah karena meriwayatkan dan menghafal rojaz lebih mudah sebab bait-baitnya lebih pendek dan wajn (timbangan)nya lebih ringan. ${ }^{5}$

Sebaiknya dalam hal ini, guru memilih sya'ir tentang adab-adab yang terpuji, kemuliaan orangorang yang berilmu dan hinanya orang-orang yang bodoh, mendorong untuk berbakti kepada orang tua, anjuran melakukan amar ma'ruf dan memuliakan tamu. Apabila anak-anak sudah bisa menghafal Al-Qur'an al-Karim dan mengetahui qaidah-qaidah bahasa Arab dengan baik, maka untuk mengarahkan ke jenjang berikutnya adalah dengan melihat kecenderungannya atau apa yang sesuai dengan tabiat dan bakatnya. Di dalam nasihat terakhir tersebut Ibnu Sina menyebutkan pengarahan guru yang disesuaikan dengan kecenderungan atau apa yang sesuai dengan bakat anak, merupakan ruh (inti) pendidikan modern di jaman kita ini. Para pakar

${ }^{4}$ A. Suradi, Pendidikan Karakter Bagi Anak Usia Dini Dalam Perspektif Pendidikan Agama Islam, HIKMAH: Jurnal Pendidikan Islam Vol. 7, No. 1, Tahun 2018, hlm. 59.

${ }^{5}$ Muhammad 'Athiyyah Al-Abrasyi, at-Tarbiyah al-Islamiyah wa Falasatuha, (ttp: 'Isa al-Babi al-Jalaba wa syirkahu, 1969), hlm. 162 pendidikan sekarang mengajak untuk selalu memperhatikan kesiapan dan kecenderungan anakanak didik dalam belajar, mereka diarahkan ke dalam masalah teori maupun praktik yang meliputi masalah adab, olah raga, agama, sosial dan kesenian sesuai dengan kecenderungan mereka, agar mereka sukses dalam belajarnya. ${ }^{6}$

Dengan demikian seluruh mata pelajaran merupakan satu kesatuan yang utuh atau bulat. Adapun pokok-pokok pendidikan yang harus diberikan kepada anak, adalah meliputi seluruh ajaran Islam yang secara garis besar dapat dikelompokan menjadi tiga, yakni, aqidah, ibadah dan akhlak serta dilengkapi dengan pendidikan membaca Al Qur'an.

1. Pendidikan akidah, hal ini diberikan karena Islam menempatkan pendidikan akidah pada posisi yang paling mendasar, terlebih lagi bagi kehidupan anak, sehingga dasar-dasar akidah harus terus-menerus ditanamkan pada diri anak agar setiap perkembangan dan pertumbuhannya senantiasa dilandasi oleh akidah yang benar.

2. Pendidikan ibadah, hal ini juga penting bagi pertumbuhan dan perkembangan anak usia dini. Karenanya tata peribadatan menyeluruh sebagaimana termaktub dalam fiqih Islam hendaklah diperkenalkan sedini mungkin dan dibiasakan dalam diri anak sejak usia dini. Hal ini dilakukan agar kelak mereka tumbuh menjadi insan yang benar-benar takwa, yakni insan yang taat melaksanakan segala perintah agama dan taat pula dalam menjauhi segala larangannya.

3. Pendidikan akhlak, dalam rangka mendidik akhlak kepada anak-anak, selain harus diberikan keteladanan yang tepat, juga harus ditunjukkan tentang bagaimana menghormati dan bertata krama dengan orang tua, guru, saudara (kakak dan adiknya) serta bersopan santun dalam bergaul dengan sesama manusia. Alangkah bijaksananya jika para orangtua atau orang dewasa lainnya telah memulai dan menanamkan pendidikan akhlak kepada anak-anaknya sejak usia dini, apa lagi jika dilaksanakan secara terprogram dan rutin. ${ }^{\text {? }}$

${ }^{6}$ Ibid, hlm. 163

${ }^{7}$ Hasan dan Andi Rusbandi Mansyur, Pedoman Guru Mata Pelajaran Ilmu Pengetahuan Sosial Untuk Madrasah Ibtidaiyah,(Jakarta:Departemen $\begin{array}{llll}\text { Agama } & \text { RI, 2005), } & \text { hlm. }\end{array}$ 
Buyung Surahman I Sistem Pendidikan Anak Usia Dini Dalam Konsep Islam

Karenanya kurikulum untuk anak usia dini sebaiknya memperhatikan beberapa prinsip;Pertama, berpusat pada anak, artinya anak merupakan sasaran dalam kegiatan pembelajaran yang dilakukan oleh pendidik. Kedua, mendorong perkembangan fisik, daya pikir, daya cipta, sosial emosional, bahasa dan komunikasi sebagai dasar pembentukan pribadi manusia yangh utuh. Ketiga, memperhatikan perbedaan anak, baik perbedaan keadaan jasmani, rohani, kecerdasan dan tingkat perkembangannya. Pengembangan program harus memperhatikan kesesuaian dengan tingkat perkembangan anak (Developmentally Appropriate Program). ${ }^{8}$

Acuan menu pembelajaran pada Pendidikan Anak Usia Dini telah mengembangkan program kegiatan belajar anak usia dini. Program tersebut dikelompokkan dalam enam kelompok usia, yaitu 0-1 tahun, 1-2 tahun, 2-3 tahun, 3-4 tahun, 5-6 tahun dan 5-6 tahun. Masing-masing kelompok usia dibagi dalam enam aspek perkembangan yaitu: perkembangan moral dan nilai-nilai agama, perkembangan fisik, perkembangan bahasa, perkembangan kognitif, perkembangan sosial emosional, dan perkembangan seni dan kreativitas. ${ }^{9}$

Sesuai dengan dasar, tujuan dan kompetensi pendidikan anak usia dini, maka ada beberapa materi pokok yang harus diajarkan kepada anak-anak di usia dini. Dalam konsep Islam, secara umum materi yang harus diajarkan kepada anak usia dini, sama dengan materi dasar ajaran Islam yang terdiri dari bidang aqidah, ibadah, dan akhlak. Dalam pembelajaran terhadap anak usia dini, tentu saja uraian materi yang diberikan tidaklah sama dengan yang diberikan kepada orang dewasa, meskipun masih berada dalam lingkup akidah, ibadah dan akhlak.

Pada bidang aqidah, meskipun anak usia dini belum layak untuk diajak berpikir tentang hakikat Tuhan, malaikat, nabi (rasul), kitab suci, hari akhir, dan qadha dan qadar, tetapi anak usia dini sudah dapat diberi pendidikan awal tentang aqidah (rukun Iman). Pendidikan awal tentang aqidah, bisa saja diberikan materi yang berupa mengenal namanama Allah dan ciptaan-Nya yang ada di sekitar

${ }^{8}$ M. Nipan Abdul Halim, Anak Saleh Dambaan Keluarga, (Jakarta: Mitra Pustaka, 2005), hlm. 12

${ }^{9}$ Depdiknas,Acuan Menu Pembelajaran pada Pendidikan Usia Dini(Pembelajaran Generik),(Jakarta: Depdiknas, 2002), hlm. 21 kehidupan anak, nama-nama malaikat, kisah-kisah Nabi dan Rasul, dan materi dasar lainnya yang berkaitan dengan aqidah (rukun Iman).

Setiap orang tua harus menyadari bahwa mengajarkan al-Qur'an kepada anak-anak adalah suatu kewajiban mutlak dan harus dilaksanakan sejak dini agar ruh al-Qur'an dapat membekas dalam jiwa mereka. Sebab bagaimana anak-anak dapat mengerti agamanya jika mereka tidak mengerti alQur'an. Selain itu untuk kepentingan bacaan dalam sholat, anak-anak pun wajib mengetahui dan dapat membaca surah Al Fatihah dan lainnya yang menjadi keperluan sebagai bacaan dalam sholat. Dengan adanya tuntutan kewajiban sholat, maka mutlak bagi orang tua wajib memberi pendidikan al-Qur'an kepada anak-anaknya. Islam juga memerintahkan untuk memberikan pendidikan membaca Al Qur-an kepada anak sejak usia dini, tentu saja dalam bentuk pendidikan awal. Pada masa sekarang ini pembelajaran membaca al Qur-an pada anak usai dini dapat diberikan dengan cara pembelajaran metode Iqra, dan ternyata metode ini banyak memberikan hasil positif bagi perkembangan dan kemampuan membaca al Qur-an anak usia dini (usia Taman Kanakkanak)

Pada usia dini anak juga perlu diberi pengajaran tentang ibadah, seperti tentang bersuci, do'ado'a, dan ayat-ayat pendek, cara mengucap salam, dan sedikit tentang tata cara melaksanakan shalat, serta beberapa hal lain yang dikategorikan kepada amal dan perbuatan baik yang diridhoi Allah. Dalam hal memberi pendidikan shalat kepada anak di usia dini dapat dilakukan orang tua dengan mulai membimbing anak untuk mengerjakan shalat dengan mengajak melakukan shalat di sampingnya, dimulai ketika ia sudah mengetahui tangan kanan dan kirinya. ${ }^{10}$ Jangan diamkan anak menonton televisi, sementara azan berkumandang. Jika orang tua menghendaki anak mengerjakan shalat, berilah ia teladan. Orang tua perlu menjelaskan bahwa shalat merupakan satu wujud rasa syukur, karena Allah telah memberikan nikmat berupa rezki yang halal dan kesehatan. ${ }^{11}$

${ }^{10}$ Muhammad Suwaid, Manhaj at-Tarbiyyah an-Nabawiyyah litTifl...,hlm. 175

"Ummi Aghla, Mengakrabkan Anak pada Ibadah,(Jakarta: Almahira, 2004), hlm. 96 
38 en 2018

Rahasianya adalah agar anak dapat mempelajari hukum-hukum ibadah shalat sejak masa pertumbuhannya, sehingga ketika anak tumbuh besar, ia telah terbisa melakukan dan terdidik untuk mentaati Allah, melaksanakan hak-hakNya, bersyukur kepada Allah, di samping itu anak akan mendapatkan kesucian ruh, kesehatan jasmani, kebaikan akhlak, perkataan dan perbuatan di dalam ibadah shalat yang dilaksanakannya. ${ }^{12}$

Selain materi-materi tersebut di atas, anak pada usia dini juga masih perlu diberikan materi pendidikan tentang kesehatan dan kebersihan badan, gerak badan (olah raga), belajar bermain dengan teman sebaya, belajar membaca dan menulis latin, belajar menghitung, menggambar, melipat, dan hal-hal lain yang bermanfaat bagi perkembangan dan pertumbuhan psiko motorik anak.

\section{Metode Pendidikan Anak Usia Dini Dalam Kon- sep Islam}

Dengan bersumberkan kepada Al Qur-an dan hadis, ada beberapa metode pendidikan Islam yang dapat dan layak diterapkan pada kegiatan pendidikan terhadap anak usia dini. Metode dimaksud adalah:

\section{Metode dengan Keteladanan}

Kegiatan yang dapat ditiru dan dijadikan panutan dan dalam hal ini pendidik menunjukkan perilaku konsisten. ${ }^{13}$ Keteladanan dalam pendidikan Islam, merupakan metode yang berpengaruh dan terbukti berhasil dalam mempersiapkan dan membentuk aspek moral, spiritual, dan etos sosial anak sejak usia dini. Hal ini karena pendidik adalah figure terbaik dalam pandangan anak didik yang tindak tanduknya dan sopan santunnya, disadari atau tidak akan menjadi perhatian anak-anak sekaligus ditirunya. Keteladanan menjadi faktor penting dalam menentukan baik buruknya pertumbuhan dan perkembangan anak usia dini. Jika pendidik dan orang tua jujur, dapat dipercaya, berakhlak mulia, berani, dan menjauhkan diri dari perbuatan-perbuatan yang bertentangan dengan agama, maka si anak akan tumbuh dalam kejujuran, terbentuk dengan akhlak mulia, berani dan menjauhkan diri dari perbuatan-perbuatan yang bertentangan dengan agama.

Anak usia dini, bagaimanapun besarnya usaha yang dipersiapkan untuk kebaikannya, ba-

${ }^{12}$ Abdullah Nashih Ulwan,Tarbiyat al- Aulad Fi al- Islam, terj. Jamaluddin Miri, Pendidikan Anak dalam Islam, (Jakarta: Pustaka Amani, 1995), hlm. 153 gaimanapun sucinya fitrah, tidak akan mampu memenuhi prinsip-prinsip kebaikan dan pokok-pokok pendidikan utama, selama ia (anak usia dini) tidak melihat pendidik dan orang tua sebagai teladan dari nilai-nilai moral yang tinggi. Kiranya sangat mudah bagi pendidik untuk mengajari anak dengan berbagai materi pendidikan, tetapi teramat sulit bagi anak untuk melaksanakannya jika ia melihat orang yang memberikan pengajaran tidak mengamalkan-nya.

Di dalam kehidupan berkeluarga misalnya, anak usia dini membutuhkan suri teladan, khususnya dari kedua orang tuanya, agar sejak dini (masa kanak-kanak) ia menyerap dasar tabiat perilaku Islami dan berpijak pada landasannya yang luhur. Keteladanan yang baik memberikan pengaruh besar terhadap jiwa anak, sebab anak banyak meniru kedua orang tuanya. Anak-anak akan selalu memperhatikan dan mengawasi perilaku orang tuanya atau orang dewasa lainnya, dan mereka akan mencontohnya, jika anak mendapati orang tuanya berlaku jujur, mereka akan tumbuh dengan kejujuran. ${ }^{14}$ Kemampuan anak dalam menerima teladan dari orang dewasa secara sadar atau tidak sadar sangatlah tinggi, meskipun anak-anak sering dianggap sebagai makhluk kecil yang belum mengerti dan paham ajaran Islam, tetapi dengan melihat teladan yang diberi orang dewasa hal itu akan memberi bekasan pada diri anak.

\section{Metode Latihan dan Pengamalan}

Dalam hal pendidikan melalui latihan pengamalan, Rasulullah SAW, sebagai pendidik Islam yang pertama dan utama sesungguhnya telah menerapkan metode ini dan ternyata memberikan hasil yang menggembirakan bagi perkembangan Islam di kalangan sahabat. Dalam banyak hal, Rasul senantiasa mengajarkannya dengan disertai latihan pengamalannya, di antaranya; tatacara bersuci, berwudhu, melaksanakan shalat, berhaji dan berpuasa. ${ }^{15}$ Sebagaimana diuraikan oleh Nuraeni, bahwa puncak dari tahap pendidikan adalah memberi kesempatan kepada anak untuk mengamalan kegiatan kebaikan. ${ }^{16}$

${ }^{13}$ Nuraeni, Pendidikan Karakter Pada Anak Usia Dini, Jurnal PaedagogyVolume 1 Nomor 2 Edisi Oktober 2014, hlm. 8

${ }^{14}$ Kedua orang tua dituntut mengimplementasikan perintah-perintah Allah dan sunnah Rasul sebagai perilaku dan amalan serta terus menambah amalan-amalan sunnah tersebut semampunya, karena anak-anak akan terus mengawasi dan meniru mereka setiap waktu, lihat: Muhammad Suwaid, Manhaj at-Tarbiyyah an-Nabawiyyah lit-Tifl..., hlm. 458

${ }^{15} \mathrm{Ibid}, \mathrm{hlm} .340$

${ }^{16}$ Nuraeni, Pendidikan Karakter Pada Anak Usia Dini,hlm. 9 
Atas dasar ini, maka dalam pelaksanaan pendidikan Islam baik kepada orang dewasa, apalagi terhadap anak-anak usia dini pendidikan melalui latihan dan pengamalan merupakan satu metode yang dianggap penting untuk diterapkan. Metode belajar learning by doing atau dengan jalan mengaplikasikan teori dan praktik, akan lebih memberi kesan dalam jiwa, mengokohkan ilmu di dalam kalbu dan menguatkan dalam ingatan. Di antara yang dapat dilatihkan sebagai amalan bagi anak-anak usia dini antaranya ialah; cara menggosok gigi, latihan mencuci tangan yang benar, cara beristinja, latihan berwudhu', mengucapkan salam ketika masuk rumah, serta beberapa do'a yang harus diamalkan sebagai mengawali berbagai aktivitas sehari-hari, seperti do'a hendak dan sesudah makan, do'a hendak dan bangun tidur, do'a masuk kamar mandi, dan do'a lain yang mudah diamalkan oleh anakanak usia dini.

Orang tua juga berkewajiban melatih mereka melaksanakan shalat, puasa dan infaq, bersedekah serta berbuat baik kepada tetangga dan orang-orang fakir, juga menolong orang-orang yang lemah. ${ }^{17}$ Disamping itu juga harus dilatih menghormati orang yang lebih tua dan telah berumur, dilatih/dibiasakan melakukan berbagai kegiatan dengan niat kerena keridhaan Allah semata, mencintai karena Allah dan membenci karena Allah. Mengorbankan harta serta diri mereka di jalan Allah, melaksana-kan kewajiban agama, menegakkan moral Islam, khususnya mengenakan jilbab bagi anak perempuan.

\section{Metode Permainan, Nyanyian, dan Cerita}

Sesuai dengan pertumbuhannya, anak usia dini memang lagi gemar-gemarnya melakukan berbagai permainan yang menarik bagi dirinya. Berkaitan dengan ini, maka pendidikan melalui permainan merupakan satu metode yang menarik diterapkan dalam pendidikan anak usia dini. Tentu saja permainan yang positif dan dapat mengembangkan intelektual dan kreativitas anak-anak. Bagi anak-anak usia balita, bermain dengan ibu tentu lebih banyak dampak positifnya karena lebih memperlancar komunikasi antara keduanya, adalah teman terbaik

${ }^{17}$ Zuhaili, Muhammad,Al Islam Wa Asy Syabab, terjemahan Arum Titisari, Pentingnya Pendidikan Islam Sejak Dini,(Jakarta: AH. Ba'adillah Press, 2002), hlm. 70 bagi mereka. ${ }^{18}$

Namun perlu diingat pula bahwa yang paling perlu orang tua usahakan pertama kali sebelum mengenalkan dan melatih bepuasa adalah mengkondisikan anak dengan lingkungan yang Islami. Kenalkan suasana puasa di lingkungan keluarga, karena suasana itu bagi anak merupakan bekal dalam mempersiapkan dirinya, sehingga anak terbiasa dengan suasana berpuasa. Anak tidak melihat ibu, bapak, dan anggota keluarganya makan di siang hari, tetapi makan ketika terbenam matahari. Perlu juga diingat adalah jangan sekali-sekali memaksa mereka melakukan puasa secara terus menerus sejak dari terbit fajar hingga terbenam matahari, namun latih mereka untuk melakukan puasa secara bertahap, mulai dari hitungan jam sampai akhirnya mereka dapat terus berpuasa dari terbit fajar hingga berbuka pada magribnya. Setelah anak mampu berpuasa selama satu hari penuh, kenalkan mereka dengan hal-hal yang membatalkan puasa. ${ }^{19}$

Agar mainan yang diberikan oleh orang tua kepada anak-anak mereka benar-benar bisa bermanfaat, maka kedua orang tua perlu mempertimbangkan; apakah mainan itu termasuk mainan yang akan membangkitkan aktivitas jasmani dan kesehatan yang berguna bagi anak. Apakah mainan tersebut membeikan kesempatan bagi anak untuk menyusunnya, dan apakah mainan tesebut bisa mendorong anak untuk meniru perilaku orangorang dewasa dan cara berpikir mereka. Jika jawaban atas semua pertanyaan tersebut adalah "ya", maka mainan tersebut berarti sesuai untuknya dan memberikan manfaat edukatif. ${ }^{20}$ Selain memberi permainan kepada anak, bermain dengan anak dan bertingkah seperti mereka dalam bergaul dengan mereka akan menumbuhkan semangat di dalam jiwanya dan juga akan membantunya menampilkan serta mengembangkan potensi-potensi yang dimilikinya.Dalam al-Ishabah dikatakan bahwa Rasulullah saw pernah bermain-main dengan Hasan dan Husin ra. Rasulullah saw. Merangkak di atas kedua tangan dan lututnya, dan kedua cucunya tersebut bergelantungan dari kedua sisinya, dan merangkak bersama keduanya. ${ }^{21}$

hlm. 130

Istadi, Irawati,Mendidik Dengan Cinta, (Bekasi: Pustaka Inti, 2006),

${ }^{19}$ Aghla, Ummi,Mengakrabkan Anak pada Ibadah..., hlm. 98

${ }^{20} \mathrm{Ibid}, \mathrm{hlm} .521$

${ }^{21}$ Abdullah Nashih Ulwan, Tarbiyat al- Aulad Fi al- Islam..., hlm. 33 


\section{MetodeTarghib dan Tarhib}

Targhib adalah janji yang disertai dengan bujukan dan membuat senang terhadap sesuatu maslahat, kenikmatan, atau kesenangan akhirat. Sedangkan tarhib adalah ancaman dengan siksaan sebagai akibat melakukan dosa atau kesalahan yang dilarang oleh Allah, atau akibat lengah dalam menjalankan kewajiban yang diperintahkan Allah. ${ }^{22}$

Ini merupakan metode pendidikan Islam yang didasarkan atas fitrah yang diberikan Allah kepada manusia, seperti keinginan terhadap kekuatan, kenikmatan, kesenangan, dan kehidupan abadi yang baik serta ketakutan akan kepedihan, kesengsaraan dan kesudahan yang buruk. Ditinjau dari segi paedagogis, hal ini mengandung anjuran, hendaknya pendidik dan atau orang tua menanamkan keimanan dan aqidah yang benar di dalam jiwa anak-anak, agar pendidik dapat menjanjikan (targhib) surga kepada mereka dan mengancam (tarhib) mereka dengan azab Allah, sehingga hal ini diharapkan akan mengundang anak didik untuk merealisasikan dalam bentuk amal dan perbuatan yang dianjurkan oleh ajaran Islam.

Dalam memberikan pendidikan melalui targhib dan tarhib, pendidik hendaknya lebih mengutamakan pemberian gambaran yang indah tentang kenikmatan di surga dan berbagai kenikmatan lain yang diperoleh sebagai balasan bagi amal sholeh yang dikerjakan, sekaligus juga diberikan sedikit gambaran tentang dahsyatnya azab Allah yang diberikan sebagai ganjaran pelanggaran yang dilakukan. ${ }^{23}$ Pendidikan dengan menerapkan metode ini merupakan upaya untuk menggugah, mendidik dan mengembangkan perasaan Rabbaniyah pada anak sejak usia dini, perasaan-perasaan yang diharapkan dapat dikembangkan melalui metode ini antara lain; khauf kepada Allah, perasaan khusyu', perasaan cinta kepada Allah, dan perasaan raja' (berharap) kepada Allah.

\section{Pujian dan Sanjungan}

Anak kecil yang masih berada dalam umur tiga tahun pertama bukannya tidak mempunyai perasaan kehormatan serta harga diri, ia menyadari bah-

${ }^{22}$ Abdurrahman An-Nahlawi, Prinsip-Prinsip dan Metode Pendidikan Islam dalam Keluarga di Sekolah dan di Masyarakat..., hlm. 412

${ }^{23} \mathrm{Tbid}, \mathrm{hlm} .414$ wasanya dirinya adalah anak kecil, akan tetapi dalam lubuk hatinya ia tidak menerima jika dianggap remeh dalam bentuk dan sikap yang bagaimanapun. Selama ia masih tumbuh berkembang maka perasaan dihargai dan dihormati ikut tumbuh kembang dalam dirinya. Perasaan harga diri dan dihormati merupakan pembawaan manusia secara fitrah, baik sebagai anak kecil maupun sebagai manusia dewasa, sebab sesungguhnya manusia merupakan makhluk yang dihormati lagi dimuliakan. Mengenai bentuk dan ragam pemberian pujian atau penghargaan cukup banyak, yang terpenting adalah anak sejak dini dipandang sebagai manusia sekaligus diperlakukan secara manusiawi. ${ }^{24}$

Secara lebih lanjut, pujian dan sanjungan dapat diberikan dalam bentuk hadiah. Namun orang tua hendaklah berhati-hati dalam memilih hadiah, agar tidak menimbulkan ketagihan. Hindarilah memberi hadiah uang, karena selain benda ini sangat menggiurkan, orang tua pun harus bekerja dua kali untuk membimbing anak agar mampu membelanjakan uangnya dengan baik. Pilihlah hadiah yang bersifat edukatif, sehingga tak jadi persoalan jika anak-anak kemudian ketagihan. Buku cerita, alat-alat sekolah serta perlengkapan kegemaran anak akan cukup menyenangkan mereka. Pilih barang yang saat itu sedang mereka butuhkan, sehingga orang tua tidak perlu membelikannya lagi, misalnya jika sepatunya sudah mulai nampak berlubang, mengapa tidak menjadikannya saja sebagai hadiah, sebab kalaupun tidak sebagai hadia toh akhirnya orang tua harus membelikannya juga. Orang tua harus sejak awal dan terus-menerus menanamkan pengertian bahwa hadiah yang diberikan kepada anak bukan semata untuk menghargai prestasi akhir mereka, namun lebih dititikberatkan pada usaha anak untuk mengubah dirinya. ${ }^{25}$

\section{Menanamkan Kebiasaan yang Baik}

Dalam usaha memberikan pendidikan dan membantu perkembangan anak usia dini, selain pengembangan kecerdasan dan keterampilan, perlu juga sejak dini ditanamkan kebiasaan-kebiasaan yang positif. Pendidikan dengan mengajarkan dan pembiasaan adalah pilar terkuat untuk pendidikan

\footnotetext{
${ }^{24}$ Quthb, Muhammad,Sistem Pendidikan Islam..., hlm. 72

${ }^{25}$ Istadi, Irawati,Mendidik Dengan Cinta..., hlm. 26
} 
41 e

anak usia dini, dan metode paling efektif dalam membentuk iman anak dan meluruskan akhlaknya, sebab metode ini berlandasakan pada pengikutsertaan. Tidak diragukan lagi, mendidik dengan cara pembiasaan anak sejak dini adalah paling menjamin untuk mendatangkan hasil positif, sedangkan mendidik dan melatih setelah dewasa sangat sukar untuk mencapai kesempurnaan. ${ }^{26}$

Itulah beberapa metode pendidikan yang menurut hemat penulis layak untuk diterapkan pada pelaksanaan pendidikan anak usia dini. Dengan metode-metode tersebut secara teoritis akan memberikan hasil positif terhadap pembinaan dan pendidikan anak usia dini, baik itu yang dilaksanakan orang tua di rumah, maupun oleh para guru di sekolah/lembaga pendidikan anak usia dini.

\section{Evaluasi Pendidikan Anak Usia Dini Dalam Kon- sep Islam}

Rangkaian akhir dari suatu proses pendidikan anak usia dini adalah evaluasi atau penilaian. Evaluasi merupakan suatu kegiatan untuk menentukan taraf kemajuan suatu pekerjaan di dalam proses pendidikan. Dalam pendidikan Islam, termasuk juga pendidikan anak usia dini, evaluasi merupakan salah satu komponen penting dari sistem pendidikan Islam yang harus dilakukan secara sistematis dan terencana sebagai alat untuk mengukur keberhasilan atau target yang akan dicapai dalam proses pendidikan dan proses pembelajaran. ${ }^{27}$

Dalam ruang lingkup terbatas, evaluasi dilakukan dalam rangka mengetahui tingkat keberhasilan pendidikan dalam menyampaikan materi pendidikan kepada peserta didik. Sedangkan dalam lingkup yang lebih luas, evaluasi dilakukan untuk mengetahui tingkat keberhasilan dan kelemahan suatu proses pendidikan dalam mencapai tujuan pendidikan yang dicita-citakan. ${ }^{28}$

Sebagai satu komponen penting dalam pendidikan, evaluasi yang dilaksanakan secara umum memiliki fungsi untuk; mengetahui peserta didik yang mana yang terpandai dan terbodoh di kelasnya, mengetahui apakah bahan yang telah diajarkan sudah dimiliki oleh peserta didik atau belum, men-

${ }^{26}$ Abdullah Nashih Ulwan, Tarbiyat al- Aulad Fi al- Islam...,64 223

${ }^{27}$ Ramayulis,Ilmu Pendidikan Islam,(Jakarta: Kalam Mulia, 2006), hlm. dorong persaingan yang sehat antara sesama peserta didik, mengetahui kemajuan dan perkembangan peserta didik setelah mengalami didikan dan ajaran, mengetahui tepat atau tidaknya guru memilih bahan, metode, dan berbagai penyesuaian dalam kelas, dan sebagai laporan terhadap orang tua peserta didik dalam bentuk rapor, ijazah, piagam dan sebagainya. $^{29}$

Mengigat pentingnya evaluasi bagi proses pendidikan, maka dalam kegiatan pendidikan yang diberikan kepada anak usia dini juga perlu dilakukan evaluasi. Terhadap kegiatan pendidikan anak usia dini, evaluasi atau penilaian dapat dilakukan dengan berbagai cara, antara lain melalui pengamatan dan pencatatan anekdot. Pengamatan dilakukan untuk mengetahui perkembangan dan sikap anak yang dilakukan dengan mengamati tingkah laku anak dalam kehidupan sehari-hari secara terus menerus, sedangkan pencatatan anekdot merupakan sekumpulan catatan tentang sikap dan perilaku anak dalam situasi tertentu.

Beberapa alat penilaian yang dapat digunakan untuk memperoleh gambaran perkembangan kemampuan dan perilaku anak, antara lain adalah:

1. Portofolio yaitu penilaian berdasarkan kumpulan hasil kerja anak yang dapat menggambarkan sejauhmana keterampilan anak berkembang.

2. Unjuk kerja (performance) merupakan penilaian yang menuntut anak untuk melakukan tugas dalam bentuk perbuatan yang dapat diamati, misalnya praktik menyanyi, olahraga, atau memperagakan sesuatu perbuatan; seperti cara menggosok gigi, cara beristinja, cara berwudhu' dan sedikit tentang gerakan dalam sholat.

3. Penugasan (project) merupakan tugas yang harus dikerjakan anak yang memerlukan waktu yang relativ lama dalam mengerjakannya, misalnya melakukan percobaan menanam biji.

4. Hasil karya (product) merupakan hasil kerja anak setelah melakukan suatu kegiatan. ${ }^{30}$

Seluruh kegiatan evaluasi yang dilakukan dalam pendidikan anak usia dini adalah untuk mengetahui perkembangan anak didik, yang mencakup dua as-

${ }^{28} \mathrm{Al}$-Rasyidin,Pendekatan Historis, Teoritis dan Praktis Filsafat Pendidikan Islam. (Jakarta:Bumi Aksara, 2004), hlm.77

${ }^{29}$ Ramayulis,Ilmu Pendidikan Islam..., hlm. 223

${ }^{30}$ Boediono, ed.,Standar Kompetensi Pendidikan Anak Usia Dini Taman Kanak-Kanak dan Raudhatul Athfal..., hlm. 13 
42 NUANSA Vol. XI, No. 1, Juni 2018uyung Surahm an | Sistem Pendidikan Anak Usia Dini Dalam Konsep Islam en

pek utama yaitu aspek pembiasan dan kemampuan dasar. Pada aspek pembiasaan, penilaian meliputi tentang perkembangan moral dan nilai-nilai agama, sosial, emosional dan kemandirian. Sedangkan pada aspek kemampuan dasar penilaiannya meliputi; kemampuan berbahasa, kemampuan kognitif, kemampuan fisik/motorik, dan kemampuan seni.

Terhadap perkembangan moral dan nilai-nilai agama, evaluasi dilakukan untuk mengetahui kemampuan anak dalam berdo'a, mengucapkan salam, membedakan cipataan-ciptaan Allah, membaca beberapa do'a pendek, sekaligus juga mengetahui perkembangan anak dalam berdisiplin, kesopanan dalam berpakaian dan ketertiban dalam mengerjakan tugas-tugas di sekolah. Adapun penilaian terhadap perkembangan sikap sosial, emosional dan kemandirian, ditujukan untuk mengetahui perkembangan kemampuan anak dalam bergaul, berteman, mengambil keputusan sederhana, bertanya sederhana, mengendalikan emosi dan kemandirian dalam mengurus keperluannya di sekolah.

Evaluasi perkembangan fisik/motorik dilakukan dalam rangka mengetahui kemampuan anak dalam hal fisik/motoriknya seperti dalam kegiatan makan, menyisir rambut, mencuci dan mengelap tangan, memantulkan, menangkap, melempar bola, menggunting, melipat, dan meniru suatu gerakan terutama dalam bentuk senam atau tarian sederhana. Evaluasi perkembangan seni adalah untuk mengetahui kemampuan anak dalam mengapresiasikan imajinasinya dalam bentuk seni, seperti menggambar bebas dengan menggunakan krayon dan pensil berwarna, mewarnai gambar, menyanyikan lagu sambil bermain, dan mengekspresikan gerak.

\section{Kesimpulan}

Berdasarkan hasil pembahasan bahwa pendidikan yang harus diberikan kepada anak usia dini, adalah meliputi; pertama, pendidikan akidah, hal ini diberikan karena Islam menempatkan pendidikan akidah pada posisi yang paling mendasar, terlebih lagi bagi kehidupan anak, agar setiap perkembangan dan pertumbuhannya senantiasa dilandasi oleh akidah yang benar. Kedua, Pendidikan ibadah, hal ini juga penting bagi pertumbuhan dan perkembangan anak usia dini. Hal ini dilakukan agar kelak mereka tumbuh menjadi insan yang benar-benar takwa, yakni insan yang taat melaksanakan segala perintah agama dan taat pula dalam menjauhi se- gala larangannya.Ketiga,Pendidikan akhlak, dalam rangka mendidik akhlak kepada anak-anak, selain harus diberikan keteladanan yang tepat, juga harus ditunjukkan tentang bagaimana menghormati dan bertata krama dengan sesama manusia.

Metode pendidikan Islam yang dapat dan layak diterapkan pada kegiatan pendidikan terhadap anak usia dini, adalah metode keteladanan, metode latihan dan pengamalan, metode permainan, nyanyian, dan cerita, metode targhib dan tarhib,metode pujian dan sanjungan serta menanamkan kebiasaan yang baik. Adapun evaluasi bagi penilaian proses pendidikan anak di usia dini dapat dilakukan dengan berbagai cara, antara lain melalui pengamatan dilakukan untuk mengetahui perkembangan dan sikap anak yang dilakukan dengan mengamati tingkah laku anak dalam kehidupan sehari-hari secara terus menerus, sedangkan pencatatan anekdot merupakan sekumpulan catatan tentang sikap dan perilaku anak dalam situasi tertentu.

\section{Daftar Pustaka}

Aghla, Ummi.Mengakrabkan Anak pada Ibadah. Jakarta: Almahira. 2004.

Ad-Dimasyqi, Al Imam abul Fida Ismail Ibnu Kasir. Tafsir Al Qur'an al-'Azim, terjemahan Bahrum Abu Bakar, Tafsir Ibnu Kasir juz 12. Bandung: Sinar Baru Algesindo. 2003.

Al-Abrasyi, Muhammad 'Athiyyah. at-Tarbiyah alIslamiyah wa Falasatuha. ttp: 'Isa al-Bbi al-Jalabi wa syirkahu. 1969.

Al-Bukhari, Abu Abdullah ibn Muhammad Isma'il. Shahih Bukhri Juz I. Riyadh: Idaratul Bahtsi Ilmiah, tt.

Al-Quzwaini, Abi 'Abdillah Muhammad ibn Yazid. Sunan Ibnu Majah, juz 1. Bairut: Dr al-Fikr, tt..

Al-Rasyidin.Pendekatan Historis, Teoritis dan Praktis Filsafat Pendidikan Islam.Jakarta:Bumi Aksara. 2004.

An-Nahlawi, Abdurrahman.Prinsip-Prinsip dan Metode Pendidikan Islam dalam Keluarga di Sekolah dan di Masyarakat.

Ar-Rifa'i, M. Nasib, Ringkasan Tafsir Ibnu Kasir, jilid 3. Jakarta: Gema Insani, 1999.

At-Tirmizi, Imam al-Hafidz Abi 'Abbas Muhammadibn 'Isa bin Saurah.Sunan at-Tirmizi al-Jami'us ahih

Depdiknas.Acuan Menu Pembelajaran pada Pendidikan Usia Dini(Pembelajaran Generik).Jakarta: Depdiknas. 2002. 
43 NUANSA Vol. XI, No. 1, Juni 2018uyung Surahm an | Sistem Pendidikan Anak Usia Dini Dalam Konsep Islam en

Halim, M. Nipan Abdul. Anak Saleh Dambaan Keluarga. Jakarta: Mitra Pustaka. 2005.

Hasan dan Andi Rusbandi Mansyur.Pedoman Guru Mata Pelajaran Ilmu Pengetahuan Sosial Untuk Madrasah Ibtidaiyah. Jakarta: Departemen Agama RI. 2005.

Ibrahim, Abu A'isy Abd Al Mun'im.Tarbiyah Al-Banati fi Al- Islam, terjemahan Herwibowo, Pendidikan Islam bagi Remaja Putri. Jakarta: Najla Press. 2007.

Istadi, Irawati.Mendidik Dengan Cinta. Bekasi: Pustaka Inti. 2006.

Muslim, Abu al-Husain ibn al-Hajjaj al-Qusyairi an-Naisaburi.Sahih Muslim Juz 1. Bandung: Al Ma'arif, tt.

Notosrijoedono, R.A. Anggraeni.Menanamkan Kecerdasan Moral Sejak Anak Usia Dini Pada Keluarga Muslim, JURNAL TARBIYAH, Vol. 22, No. 1, Januari-Juni 2015.

Nuraeni.Pendidikan Karakter Pada Anak Usia Dini, Jurnal PaedagogyVolume 1 Nomor 2 Edisi Oktober 2014
Panitia Muzakarah Ulama, Memelihara Kelangsungan Hidup Anak Menurut Ajaran Islam. Jakarta: Kerjasama Departemen Agama, MUI dan UNICEF. 1988.

Ramayulis.Ilmu Pendidikan Islam. Jakarta: Kalam Mulia. 2006.

Suradi, A. Pendidikan Karakter Bagi Anak Usia Dini Dalam Perspektif Pendidikan Agama Islam, HIKMAH: Jurnal Pendidikan Islam Vol. 7, No. 1, Tahun 2018.

Suwaid, Muhammad.Manhaj at-Tarbiyyah an-Nabawiyyah lit-Tifl, terjemahan Salafuddin Abu Sayyid, Mendidik Anak Bersama Nabi. Solo: Pustaka Arafah. 2003.

Ulwan, Abdullah Nashih.Tarbiyat al- Aulad Fi al- Islam, terj. Jamaluddin Miri, Pendidikan Anak dalam Islam. Jakarta: Pustaka Amani. 1995.

Zuhaili, Muhammad, Al Islam Wa Asy Syabab, terjemahan Arum Titisari, Pentingnya Pendidikan Islam Sejak Dini. Jakarta: AH. Ba'adillah Press. 2002. 
44 NUANSA Vol. XI, No. 1, Juni 2018uyung Surahm an | Sistem Pendidikan Anak Usia Dini Dalam Konsep Islam 